\title{
Economic Development Strategies in the Dominican Republic
}

\author{
Susan Pozo ${ }^{1}$, José R. Sánchez-Fung ${ }^{2}$, \\ and Amelia U. Santos-Paulino ${ }^{3}$
}

October 2010

\begin{abstract}
The paper documents the economic development strategies pursued by the Dominican Republic. The study argues that the country's success results from the implementation of a three-pronged economic development strategy. The first prong relates to diversifying production and the second to developing special economic zones. These zones operate in parallel fashion to the rest of the economy but with protections from domestic impediments to growth and progress. The third item in the recipe involves maintaining ample economic and social engagement with the rest of the world. The paper also highlights challenges that the country faces going forward.
\end{abstract}

Keywords: economic development strategies, primary commodities, special economic zones, economic openness, Dominican Republic

JEL classification: O2, O54

${ }^{1}$ Western Michigan University, ${ }^{2}$ Kingston University and ISA, University of London, 3 UNU-WIDER. Corresponding author: susan.pozo@wmich.edu

This study has been prepared within the UNU-WIDER project on Country Role Models for Development Success, directed by Augustin Kwasi Fosu.

UNU-WIDER gratefully acknowledges the financial contributions to the project by the Finnish Ministry for Foreign Affairs, and the financial contributions to the research programme by the governments of Denmark (Royal Ministry of Foreign Affairs), Finland (Finnish Ministry for Foreign Affairs), Sweden (Swedish International Development Cooperation Agency-Sida) and the United Kingdom (Department for International Development). 


\section{Acknowledgements}

The paper was prepared for UNU-WIDER's project 'Country Role Models for Development Success'. We thank Augustin K. Fosu for encouraging us to work on the project, and for comments and suggestions on a previous version of the paper. We also thank Eliana Cardoso, our conference discussant, and Paul Auerbach, Tony Thirlwall, and participants at UNU-WIDER's conference on 'Country Role Models for Development Success' held 13-14 June 2008 in Helsinki, Finland. Aida González, George Uwaoma Nwaogu, and Stephen L. Kragt provided able research assistance. Any remaining errors are our own.

The World Institute for Development Economics Research (WIDER) was established by the United Nations University (UNU) as its first research and training centre and started work in Helsinki, Finland in 1985. The Institute undertakes applied research and policy analysis on structural changes affecting the developing and transitional economies, provides a forum for the advocacy of policies leading to robust, equitable and environmentally sustainable growth, and promotes capacity strengthening and training in the field of economic and social policy making. Work is carried out by staff researchers and visiting scholars in Helsinki and through networks of collaborating scholars and institutions around the world.

www.wider.unu.edu publications@wider.unu.edu

UNU World Institute for Development Economics Research (UNU-WIDER)

Katajanokanlaituri 6 B, 00160 Helsinki, Finland

Typescript prepared by Lisa Winkler at UNU-WIDER

The views expressed in this publication are those of the author(s). Publication does not imply endorsement by the Institute or the United Nations University, nor by the programme/project sponsors, of any of the views expressed. 


\section{Introduction}

Understanding economic development strategies and how they affect the growth prospects of an economy is essential. But finding a recipe to promote economic growth and development that is applicable across countries is a complex task. The topic is the focus of a large and growing literature, e.g., Dixit (2007), Rodrik (2007) and Easterly (2006, 2009). This paper contributes to this discussion by analysing the Dominican Republic's successful economic development experience in modern democratic times-comprising the second half of the twentieth century and the beginning of the new millennium.

The Dominican Republic is a relevant country to study as a role model of development success given the many legacies and characteristics that it shares with other developing economies. While experiencing the same challenges, the Dominican Republic has enjoyed comparatively rapid economic growth and improvements in a variety of development indicators. Examples include life expectancy gains, rising from 59 years in 1970 to 72 years by 2007 (World Development Indicators 2009), 1 reductions in the percentage of the population, aged 15 to 24, considered illiterate from 21.5 per cent in 1970 to 7.4 per cent in 2005 (UNESCO) 2 and sustained levels of rapid per capita real GDP growth. Figure 1 plots the latter from 1969 through 2003 using World Penn data.

Of note is comparative economic information, displayed in Table 1, revealing that the Dominican Republic ranks as the fastest growing economy in Latin America, averaging 3.2 per cent per annum over the 1970-2003 period. As a yardstick, Panama's growth was only 2.44 per cent per year and Chile's 2.23 per cent. Yet the figures in Table 1 reveal that economic growth in the Dominican Republic has been relatively stable as indicated by the standard deviation of the growth rate over the period. While the country was not immune to the international crises of the 1980s and beyond, 3 almost two-thirds of Latin American economies have experienced greater volatility in output. What accounts for the Dominican Republic's relative serenity and ability to sustain rapid economic growth?

The paper argues that the Dominican Republic implemented a multifaceted development strategy consisting of three main pillars. Each pillar builds on the others, providing a stable base on which to grow and develop the economy. Individually, the pillars cannot explain success, but rather, in conjunction with each other they provide the appropriate conditions for economic progress.

The individual policies making up the three pillars have been pursued in other economies and in other circumstances, but it is argued that in isolation and in their usual form they are less likely to succeed in their overall objective. But by pursuing all three simultaneously, the Dominican Republic was able to build a strong foundation, enough to break away from relatively slow paced and more erratic economic development. In

1 Available at: http://data.worldbank.org/indicator

2 Available at: /www.uis.unesco.org/ev.php?ID=2867_201\&ID2=DO_TOPIC

3 Ocampo (2004) documents economic reform efforts and economic performance in Latin America during the late 1980s and early 1990s. 
concert the three sets of policies overcame common economic and political impediments to economic growth that were unlikely to be surmounted on their own.

The first pillar to the development strategy was to build a diversified economic base, to provide the foundation for smoothing aggregate income and for withstanding the normal gyrations of the world economy. The second pillar involved developing special economic zones (parallel economies) that protected the new industries that comprised the more diversified economic base. But the protection afforded to those industries was not 'old time' protectionism from the international economy, but rather protectionism from the domestic legal, political and economic infrastructure. These special economic zones seemed to have worked well because they provided ideal conditions for the success of capital investment, permitting these industries to achieve returns that could never have been achieved if they had instead operated in the regular domestic economy.

The third pillar pursued was to embrace openness to globalization. While many other countries have been open to globalizing forces, the special circumstance of the Dominican Republic allowed them to take advantage of 'globalization' in a more fundamental and grassroots basis. As explained, the Dominican Republic's experience with globalization permeates deeper and more generally, differing considerably from other countries' experiences with globalization which tend to be more superficial in nature.

While the strategies, pursued independently of each other, have failed to foster economic development in countries around the globe, we show that in combination and in the Dominican context, they successfully moved the Dominican Republic onto the fast-track for development. Sections 2 through 4 recount the three sets of policies along with the environment in which they were implemented. Section 5 synthesizes the investigation's key arguments, stressing the complementarities and synergies that exist with respect to the three sets of policies and highlights challenges the Dominican Republic faces going forward.

\section{Structural reforms and diversification}

Much lip service has been paid to the idea that developing countries need to diversify for the export market. The single commodity exporter may be awash with revenues from current world prices for the commodity it produces, but export earnings can plummet on account of changes in world market conditions, the entry of new producers, or natural disaster. It seems clear that official Dominican policy recognized these perils, and as did many other economies, strove to diversify economic production early on, accounting for the first pillar of the overall economic programme. The path was not smooth and policy needed to be reconfigured along the way. We recount this experience below.

Following the restoration of democracy in the early1960s, after a 30-year dictatorship, the Dominican Republic experienced a period of sustained economic growth. From 1966 through 1976 the economy expanded by nearly 8 per cent per year, realizing one of the highest growth rates in the world at the time. Over the period the economy was highly concentrated in producing and exporting primary commodities. But large fluctuations in revenues tend to be the norm for industries linked to world commodity markets and in response the Dominican government embarked on a programme to 
restructure the real economy, diversifying its production and trade structures away from primary commodities.

At the beginning of the 1970s relatively few commodities accounted for a large share of total export earnings: cocoa, coffee, sugar and tobacco. Table 2 shows that these commodities amounted to over 70 per cent of total exports, but by the new millennium, primary commodities' share made up less than 5 per cent of total exports.

The government, assuming a more active role, embarked on a protectionist import substitution industrialization (ISI) strategy, similar to programmes implemented in the rest of Latin America. Protectionist policies included imposing quantitative and administrative restrictions on imports, maintaining overvalued exchange rates and directing government investment in key industries (Cardoso and Helwege 1995). The initial and most significant programme involved nurturing specialization in manufacturing while protecting domestic producers from foreign competition.

The Industrial Incentive Law (Law 299) introduced in 1968 in conjunction with the establishment of the Industrial Development Board, resulted in the implementation of an industrial policy, focusing on developing more mining, construction and tourism. Trade policy was also legislated, involving the institution of a complex tariff code, additional duties, contingents, licenses, prohibitions, exemptions and concessions to specific industries, mostly manufacturing domestic industries competing with the importing sector. The array of restrictions was coupled with a multiple exchange rate system (see Santos-Paulino 2006). Before the 1990 tariff reform, there were 27 fiscal laws that administered the regimes applied to imports and 140 different taxes and duties (WTO 1996). 4

The assembly manufacturing industry began to dominate industrial activity in the 1980s with assembly manufacturing employment rising from 16,000 to over 100,000 from 1980 to 1990 and the sector's share of exports jumping from 11 per cent to more than 33 per cent during the period (Dauhajre et al. 1989). Tourism experienced a similar expansion with revenues surpassing sugar earnings for the first time in 1984 and earnings from all merchandise exports by 1989.

While industrial policy created the base for promoting and establishing an inexistent industrial sector, inefficient policies in tandem with other market imperfections limited the outward orientation and success of the domestic industries. That is, after a manifested effort by the government to promote industrial development and diversification of trade, commercial policy turned inefficient chiefly because it relied on the use of complex instruments, mostly in the form of tariffs and non-tariff barriers and direct subsidies to specific industries.

In addition, world events such as the increases in oil prices, the international debt crisis and the global recession contributed to the poor performance and brought to surface the inadequacies of the system for promoting sustained growth and development. 5 The

4 Import prohibitions included textiles, food and electronic products, shoes, cars and luxury items. The prohibitions were justified on the grounds of encouraging national production, and to enable the country to balance its trade account.

5 Calvo et al. (1989) is a useful reference for understanding the problems during the 1980s. 
Dominican Republic was further disadvantaged by the forty-year low in world sugar prices and the tightening of US sugar import quotas, significantly reducing Dominican sugar exports. The external shocks and unprecedented high interest rates on foreign loans pushed the economy into a cycle of balance of payments deficits and growing external debt: the culprits of a first-generation exchange rate crisis (Krugman 1979).

It became evident that the policies, in their current form, were not going to move the economy forward. To tackle the late 1980s crisis, a new stabilization and structural adjustment reform package was implemented in the early 1990s (Prazmowski 2002). The programme included reforms of tariffs and taxes and of the financial system. Tariff and tax reforms were aimed at increasing the efficiency of the existing structure while maintaining fiscal equilibrium, simplifying the tariff structure, reducing tariff dispersion and effective rates of protection and eliminating price distortions. 6 The trade policy regime became more neutral, increasing the international competitiveness of Dominican exports and reducing the anti-export bias documented in Dauhajre (1994).

While there was progress with these reforms, the Dominican economy still did not takeoff. Despite the loans and incentives made available by successive credit incentive programmes, progress was not robust. ISI in and of itself could not deliver sustained economic development. Furthermore, the autocratic government ruling until 1961 had not carried out institutional changes that safeguarded property rights, law enforcement and other economically beneficial structures needed to foster competitive market structures limiting further the ability for the Dominican incentive programmes to be successful.

A new approach was necessary to deal with this weakness. In response the second policy pillar - the creation of parallel economies which could in effect serve as safe or special economic zones for the growth of industries seems to have helped overcome this deficiency. But what was unique about these special economic zones was that the economic units within them were offered protections, not from foreign competition, but rather from domestic inefficiencies and impediments to progress.

While the push for production diversification was vigorously pursued in the Dominican Republic using techniques similar to those followed elsewhere, success was limited, at least in part, because the institutional makeup of the economy could not support the success of these new industries. We now turn to the solution of this problem as experienced by the Dominican Republic.

\section{Special economic zones}

Pillar two of the Dominican Republic's development strategy was to encourage real economic production, but within the framework of more dependable infrastructure and institutions, easing the way for foreign investment in the capital stock of the economy.

6 The September 1990 tariff reform (Decree 339/90) reduced the tariff range initially from 0-200 per cent to 5-35 per cent, and then to 0-35 per cent. The tariffs applied to imported inputs and intermediate and final goods were reduced. A new tariff code based on the 'Harmonised System of Goods Codification’ was introduced. Tariff exemptions granted to specific sectors under special agreements with the government were eliminated and import prohibitions, with a few exceptions, were removed. 
The correct setting for this strategy required first that the 1990s macroeconomic reforms were instituted. These were important for encouraging inflows of foreign direct investment (FDI) into the Dominican Republic.

In addition, the congress passed an FDI law eliminating restrictions on foreign companies investing in certain economic sectors and allowing the repatriation of profits and the channeling of long-term loans. With the macroeconomic reforms and the elimination of foreign investment restrictions firmly in place, the Dominican Republic concentrated in fostering two industries operating in many respects in a parallel fashion with respect to the overall economy: the tourism and the free trade zone (FTZ) industries.

The tourism industry and the FTZs were not fully integrated with the rest of the economy and hence operated as parallel economies in what can be described as special economic zones. Recognizing the need for special conditions to foster growth and development of industry, yet not being able to create these conditions en mass for the overall economy, these two sectors were accorded a special status either through formal official policy (as with respect to FTZs) or simply due to special circumstances necessary for the industry to operate (as in the case of the tourism industry).

The tourism industry grew rapidly, not in the major population areas, but where the necessary natural resources were located in the more remote regions of the nation. It was accorded 'special status' by virtue of its location. Necessary infrastructure did not exist in these areas. Instead, the infrastructure was developed and operated in a fashion conducive to the growth of the economy, often privately.

Given their location, isolation and vintage, tourism and FTZs did not depend on overworked and depreciated infrastructure and they were less subject to economic distortions and to opaque institutions. These protections from domestic political inefficiencies and infrastructure inadequacies seemed to greatly encourage foreign investment in these special economic zones.

Fiscal revenues from tourism grew to US\$170 million in 2006 from US\$86 million in 1998.7 Total non-resident air passenger arrivals into the country rose by 72 per cent over the same time period, a 9 per cent annual increase. 8 In addition, the changing structure of the tourism economy in the Dominican Republic contributed toward stabilizing economic production. Although net revenues from tourism are sensitive to exchange rates and economic conditions in the international economy, the country diversified the geography of tourism revenues.

Figure 2 displays information on the regional source of tourists, indicating greater diversification by source region over time. Whereas over 50 per cent of tourists to the Dominican Republic were European in 1999, the Dominican Republic smoothed the mix by reducing the European percentage to about 43 per cent while increasing the percentage originating from the USA and Canada for a combined 48 per cent, helping

7 From Ingresos Fiscales Relacionados con el Turismo, available at: http://www.bancentral.gov.do/estadisticas.asp?a=Sector_Turismo.

8 See footnote 7. 
the economy better withstand variations in demand for tourism services due to exchange rate changes and regional business cycles.

In the FTZs, light manufacturing along with some service export production developed in the major population areas but within the designated zones. The extensive system of FTZs, specializing mainly in the production of textiles (e.g., Kaplinsky 1993), has been impressive. While operating in parallel fashion to the rest of the Dominican economy, they interact and trade with the domestic economy subject to applicable tariffs and regulations and through the generation of employment and payment of some operation costs. FTZ enterprises are exempt from paying corporate income taxes, construction taxes, fees related to the registration of loan agreements, charges concerning transfers of real estate and standard import duties. In effect, the FTZs are sheltered from institutions that sometimes exact arbitrary payment in time and resources permitting this sector to prosper and grow.

Along with the structural reforms instituted in the early 1990s to make trade policy more competitive and thereby promote the FTZs, the government has used publicly financed credit to both expand and domesticate the FTZ sector. The incentives were established and administered by the Central Bank of the Dominican Republic's Investment Fund for Economic Development (Fondo de Inversiones para el Desarrollo Económico-FIDE). The role of such funds in promoting growth and development was widely contended at the national level and, in particular, the involvement of the Central Bank was questioned.

The main argument was that the role of the Central Bank is to promote price and exchange rate stability and not to perform as a planning office or development agency. However, the Central Bank was placed into the business of distributing such incentives because of the institutional weaknesses of the ministries and other government centralized agencies. The controversy, however, forced its abolishment resulting in a decline in public financing for exports, effectively subjecting FTZs to financing in the private capital markets by the mid-1990s. Figure 3 and Table 4 show that nonetheless, the sector has grown rapidly, attracting most of the foreign capital invested in the Dominican Republic and by the year 2000 generating more than 80 per cent of merchandise goods exports.

Nonetheless, the spreading of development to the economy at large requires that economic infrastructure of a certain nature permeate the rest of the economy. Production diversification mainly in the context of special economic zones cannot, on its own, spread economic development to the rest of the economy. How does a nation connect and fill in the intervening areas to promote overall development?

\section{Engagement with the rest of the world}

The third pillar of the Dominican Republic's economic development strategy involved allowing and embracing extensive engagement with the rest of the world. This engagement has benefited the Dominican Republic, providing resources, stimulating the development of important infrastructure and providing a safety valve to reduce conditions likely to lead to social unrest. More specifically, the engagement has afforded the Dominican labour and capital markets' greater flexibility. Openness has also facilitated the flow of knowledge, of international trade and of human capital to 
benefit economic development. Engagement with the rest of the world has led to investment in infrastructures vital for development and it has reduced the tendency for small shocks to generate currency and financial crises.

Studies that draw an association between openness and economic growth usually focus on narrow indicators of openness such as the share of exports in GDP or the volume of FDI in relation to the size of the economy. Greater levels of international trade are presumed to promote growth by subjecting the economy to outside influences and to competition (Lucas 2009). Competition creates pressures for more efficient production of output; larger markets facilitate the attainment of economies of scale; technology transfers accompanying FDI lead to improvements in the organization of production and in factor productivity. While cost efficiencies, economies of scale and technology transfers are often cited as contributing towards economic growth, few stress the notion that labour migrations can also speed economic growth. And yet, it is this aspect of openness that has had such a profound impact on the Dominican economy.

The Dominican Republic provides a good example of a country that interacts a great deal with the rest of the world through avenues other than merchandise trade or FDI. Migration and its by-products have stimulated economic growth in a variety of ways, making important contributions to the development of the Dominican economy. Dominican migration networks, initiated in the 1940s and 1950s with a small number of political refugees, have been etched deeper and have become more pervasive with the advent of substantial levels of economic migration from the 1960s and onwards (Hernández 2004). Dominicans continue to emigrate to the US and Spain and other areas, while older emigrant cohorts return home-sometimes on a temporary basis and sometimes with the intention to return home permanently.

Migration flows have had important and profound effects on the Dominican Republic by virtue of their size and impacts. Table 5 measures Latin American nations' migration engagement with the rest of the world by summing immigrants with emigrants and reporting the result as a share of the total population. The table reveals that in comparison to other Latin American countries, the Dominican Republic is the most engaged with the rest of the world by this measure. This engagement provides an expanded network for human and financial capital to travel to and from the Dominican Republic. In a study by Pozo et al. (2011), the significant and large contributions of migration openness of the Dominican Republic to the economic growth of the Dominican Republic is estimated and shown to be substantial. Migration openness influences the Dominican Republic and provides ripe conditions for growth through four avenues - trade, capital investments, infrastructure production and macroeconomic stability.

Migration tends to increase trade in goods and services, through what is referred to as nostalgic trade. 9 The very substantial Dominican population living outside the Dominican Republic, in particular in the United States and Spain, has likely contributed

9 See for example Mundra (2005) for discussion of this channel. 
to the surge in Dominican exports. Exports as a percentage of Dominican GDP was 3 per cent in 1999, but had risen by 2007 to nearly 6 per cent. 10

There is considerable evidence that return migration has greatly stimulated the development and accumulation of both physical and human capital on Dominican soil. On a grassroots basis, Portes and Guarnizo (1991) describe the rise of 'tropical capitalists' from this migration.11 Dominicans acquire entrepreneurial expertise during their foreign residencies, they return to the Dominican Republic and establish successful businesses that contribute to the diversification of the economic base.

Along the same lines, using household level data, Amuedo-Dorantes and Pozo (2006) trace the use of remittances to further growth in existing Dominican microenterprises. The two lines of research seem to be suggesting that return migrants partner with remaining kin abroad to build businesses in the Dominican Republic, the former providing the human capital, the latter the financial backing for capital expansion. In addition studies show that migrants abroad use their financial resources (in the form of remittances) to further the education of children in the Dominican Republic (AmuedoDorantes and Pozo 2010). Hence migration has tended to promote investments in physical, human and entrepreneurial capital which, in turn, are important for speeding economic progress and providing a better springboard to develop the economy.

Migration is also associated with producing infrastructure and general conditions conducive to economic growth. For example, pervasive migration stimulates the development of communications services so that family members living in different countries and continents can stay in touch with one another. Demands for these communication services pave the way for substantial investments in information technology. It is well-known that investments in information technology have produced large productivity gains (e.g., Jorgenson et al. 2008). These same gains can help propel economies onto an upward growth trajectory.

In addition, remittances sent to family back home, and often living in remote regions of a country, provide incentives for financial intermediaries to locate in these remote migrant sending areas (see Demirgüç-Kunt et al. 2008), further developing the banking infrastructure and spreading the wealth from development. Using information from the 2002 Dominican census, Figure 4 suggests that Dominican provinces with a higher proportion of remittance receiving households also have a higher proportion of households with telephone service, linking migration with the diffusion and development of infrastructure.

Research also suggests that countries with large remittance inflows tend to have more stable capital flows. Sudden stops of capital inflows are less likely to be observed in nations that receive substantial inflows of workers' remittances (Bugamelli and Paterno 2005). Economic investors expect migrants' inflows to continue regardless of cyclical conditions, reducing the probability of exchange rate and liquidity crises and the likelihood that economic investors will repatriate investments during stressful economic

10 Calculated by the authors from 'Valor de las Exportaciones Nacionales por Año Segun País de Destino’ available at: http://www.one.gob.do/index.php?module=articles\&func=view\&catid=204 'and World Development Indicators 2009 (see footnote 1).

11 Solimano (2008) contains papers on the international mobility of talent and economic development. 
times. The countries can therefore count on more steady access to capital for economic growth. For example, the standard deviation of yearly capital inflows 12 over the past decade for the Dominican Republic is 1.24, a lot lower than that observed for Venezuela (2.1) or for Argentina (3.19). At the same time the Dominican Republic has significantly more remittance inflows, averaging over the same period 7 per cent of its GDP in comparison to Venezuela and Argentina in which cases remittances averaged less than 1 per cent of GDP.

The engagement of the Dominican Republic with the rest of the world appears to have nourished and built resiliency into the economy. Continued infusions of physical capital, human capital and infrastructure can be directly traced to the migrations of Dominicans to other areas around the globe. Periods of negative growth due to the financial and banking crises experienced by the Dominican Republic have tended to be shorter when compared with other Latin American countries. Migration networks continue to feed capital to the nation, helping stabilize the capital markets during turbulent times.

While not escaping the aftermath of global economic shocks, the Dominican economy tends to rebound relatively quickly. This is evident in Figure 5 which presents the time series of economic growth for eight Latin American nations over the years of the study. The periods of negative economic growth experienced in the Dominican Republic never persist beyond two years. In the other countries, downturns tend to persist for longer periods of time and the recessions appear deeper. The Dominican Republic is less sensitive to financial stresses, this resiliency stemming from the ability of the country to avail itself of resources from abroad (e.g., remittance inflows) in times of need. In addition, migrant networks facilitate the flow of labour (in or out of the country) as necessary. Greater labour market flexibility allows for faster speeds of adjustment, permitting economies to continue on their growth paths.

One might ask, is the Dominican Republic different from other countries that engage with the rest of the world. If we look at Table 5 several other countries in Latin America appear in the same company as the Dominican Republic, with ratios of immigrants plus emigrants (as a share of total population) exceeding 10 per cent. But one can argue that the Dominican experience is different. First, most of emigration that has taken place in many of the countries of Latin America that have experienced considerable outmigration can be attributed to longstanding and contentious political conflict, as for example in the cases of Nicaragua and Honduras. Alternatively, as in the case of Haiti, longstanding out-migration has taken place on account of the severest of economic conditions. Haiti has long been the poorest country in the Western Hemisphere, with massive levels of poverty.

In either case, whether migrants are political refugees or escaping dire economic conditions, there is less desire for those migrants to engage with their home communities or consider returning in the longer run. But neither is the case for the Dominican Republic. While a vast majority of Dominican emigrants can be classified as economic migrants (emigrants seeking to improve their economic standing by migrating

12 Financing via the international capital markets as a per cent of GDP, obtained from World Development Indicators 2009 (see footnote 1). 
to areas with more lucrative work opportunities) the profile of the Dominican emigrant does not suggest him or her to have originated from the most poor.

Using the 2002 Dominican census, Amuedo-Dorantes and Pozo (2010) tabulate the percentage of households who claim to have a family member abroad according to the educational attainment of the household head. About 9 per cent of households with heads claiming no education (and thus likely to originate from poor households) report having at least one family member abroad. The comparable statistic for heads claiming 24 years of education (and hence likely to originate from households with a high socioeconomic status) is 12 per cent. Comparing across all education levels, the data suggest that the likelihood of having a migrant family member rises slightly with educational attainment of the head suggesting that the richer the household the more likely migration takes place. Nonetheless, the incidence of migration is well represented among all socioeconomic groups in the Dominican Republic.

Being neither a political refugee nor someone from the ranks of the desperately poor, the typical Dominican emigrant continues to have considerable contact with the home family and home country, contributing toward its progress by sending remittances for capital investment, by contributing toward the education of family back home and by returning home with entrepreneurial talents. While many Dominican emigrants surely contribute to the family for basic needs, there appears to be a substantial level of productive investment taking place as well.

\section{What we have learned}

The Dominican Republic pursued a three-pronged approach to growing its economy involving production diversification in the context of special economic zones while engaging extensively with the rest of the world. The thesis made here is that the three sets of policies, in concert, have provided a role model for economic development that has proved successful for the Dominican Republic. While these policies, individually, have been pursued before, it is the interaction of the three that seem to have propelled the country onto a steady path upward. The three policies together have interacted with each other in positive ways.

Industrial policy implemented to promote diversification is more likely to succeed in the context of special economic zones because of the protection afforded to the expanding industries from inefficient and poor functioning domestic infrastructure. Engagement with the rest of the world through migration and its by-products provides resources to better the infrastructure, to improve the efficiency of newer industries and to stabilize the economy in terms of its social needs. In additions, since migrants from the Dominican Republic originate from all walks of life, from the poor, the middle class and the rich, and since they originate from both rural and urban areas, they have created links all through the economy helping spread the economic gains.

In concert the three pillars have provided a stable basis for growth and development, but the question arises as to whether the continuation of this approach is viable in the long run. The Dominican Republic, as other middle income countries, faces the challenge of further diversifying its production and trade structures. According to existing research, countries wishing to proceed need to diversify their productive frameworks, and evolve 
from labour-intensive, low-skill production (the FTZ model) to higher value added and more skill technology-intensive activities (Hausmann et al. 2007).

The productivity embodied in exports seems to be a relevant factor. Santos-Paulino (2008) finds that export productivity is determined by a country's fundamentals: real income and human capital endowment, alongside key macroeconomic variables like exchange rates. Santos-Paulino confirms that there are important differences in the export productivity and specialization profiles of countries with comparable per capita income levels. The findings highlight the importance of not just the volume of exports, but the type of specialization patterns, favored by higher income and more technologically developed product categories.

The results can also be interpreted as evidence of the productivity enhancing effects of higher technology manufactured exports and of the productivity limiting effects of primary resource based exports. Moving up will likely require a more sophisticated workforce, one that is endowed with greater levels of human capital. Concentrating on its human resources is important, as is focusing on income distribution.

The Dominican Republic's involvement in the global economy has remained strong, as shown by the evolution of trade in goods and services, investment flows and family remittances, which have a significant share in the economy. But the dual nature of the country's industrial sectors remains a challenge. That is, over and above the incentives granted to firms producing under the FTZs regime, agriculture continues to be supported through measures like higher than average applied tariffs, direct payments, quotas and marketing and price control programmes. Despite the incentive bias, manufactures represent over 30 per cent of GDP and over 50 per cent of total national exports, compared to the lower value added in agriculture (Santos-Paulino 2010). But, as discussed in this and the preceding sections, it is the services industry that dominates the Dominican economy, mainly via tourism-related activities. It is important that the Dominican Republic continues to diversify the economy and not fall prey to relying on a single high-growth sector.

The benefits accruing to a nation that promotes tourism are a source of concern. The claim is sometimes made that a disproportionate level of proceeds from tourism accrues to foreign investors, providing little to the local population. For instance, the direct contribution of activities related to travel and tourism to the Dominican Republic's GDP has decreased from nearly 7 per cent in the late 1980s to 5 per cent in 2006. Travel and tourism employment input as a share of total employment has been 5 per cent, on average, during 1988-2006. Export earnings from international visitors and tourism goods comprising all indirect tourism-related activities have been variable, generating between 42 and 31 per cent of total export.13

Given that the most popular tourist areas in the Dominican Republic are in remote regions of the country and far away from the major population areas, the notion that tourism provides few economic opportunities for the general population is pertinent and needs to be addressed. All-inclusive pre-paid vacation packages further limit linkages and opportunities for the poorer sectors, as visitors in such situations tend to carry little

13 See World Travel and Tourism Council:

http://www.wttc.travel/eng/Tourism_Research/Tourism_Satellite_Accounting_Tool/ 
cash and they tend to remain in the tourist compounds. While León (2007) finds that, on average, the affected Dominican populations expressed considerable satisfaction in tourism-dependent occupations, it would be sensible to implement policies to spread the gains and the capital investments more widely.

Continued success with the overall Dominican model will require that production within the FTZs evolve from current low-skill production to higher-skill technology-intensive production. Low-skill producers will be egged out by newer players entering the global market place. The ability to switch gears and move up the ladder will certainly come into play in determining whether the Dominican Republic continues to prosper in the longer run. Investments in human capital will facilitate such progression and will help in fostering the creation of high quality employment (see the related discussion in Alemán 1996).

While this inquiry did not address or consider measures of income distribution over time, monitoring of such is warranted because political stability and the ability to continue shaping the economy in ways that generate economic growth will depend on the willingness to share gains from economic growth with the less fortunate. The latest UN Human Development Report shows the Dominican Republic in a rather unfavourable light with a Gini index of 52 indicating considerably more inequality in relation to the US (41), Spain (35), or Uruguay (45).14 Engaging with the rest of the world has provided for some relief from possible social disintegration. But it will be impingent on those in power to step up and prevent the rise in tension by ensuring that gains from the economic progress are more widely shared.

Other significant issues, ranging from the role of savings mobilization (Thirlwall 2004) and dealing with political economy issues (Andújar-Scheker 2008) to the importance of consolidating the institutional framework for safeguarding macroeconomic stability, mainly fiscal and monetary policies and their relationship to other parts of the economy, 15 also merit further attention. Reforming fiscal policy institutions is also of great importance.

\section{References}

Alemán, J. L. (1996). 'Lucha Contra la Pobreza, Enfatizando la Generación de Empleo’. In PUCMM/CUEPS, Agenda Nacional de Desarrollo: Planes de Acción Para las Diez Principales Prioridades, vol. 2. Santo Domingo: Grupo de Acción por la Democracia (GAD)/Editora Centenario.

Amuedo-Dorantes, C, and S. Pozo (2006). 'Remittance Receipt and Business Ownership in the Dominican Republic'. World Economy, 29: 939-56.

(2010) 'Accounting for Remittance and Migration Effects on Children's Schooling'. World Development, forthcoming.

Andújar-Scheker, J. G. (2008). 'The Political Economy of Policy Reform: The Case of the Dominican Republic’. Investigación Económica, 67: 95-129.

14 United Nations Human Development Report 2007-8, http://hdrstats.undp.org/indicators/147.html.

15 Lizardo and Guzmán (2005) analyse fiscal policy and the environment in the Dominican Republic. 
Bugamelli, M., and F. Paterno (2005). 'Do Workers' Remittances Reduce the Probability of Current Account Reversals?’. Working Paper 3766. Washington, DC: World Bank.

Calvo, G., R. Findlay, P. Kouri, and J. Braga de Macedo (eds) (1989). Debt, Stabilization and Development: Essays in Memory of Carlos Díaz-Alejandro. Oxford and New York. Basil Blackwell for UNU-WIDER.

Cardoso, E., and A. Helwege (1995). Latin America's Economy: Diversity, Trends, and Conflicts. Cambridge, MA: MIT Press.

Dauhajre, A. (1994). Sesgo Anti-exportador y Promoción de Exportaciones en la República Dominicana. Santo Domingo: Banco Central de la República Dominicana.

Dauhajre, A., E. Riley, R. Mena, and J. A. Guerrero (eds) (1989). Impacto Económico de las Zonas Francas Industriales de Exportación de la República Dominicana. Santo Domingo: Fundación Economía y Desarrollo.

Demirgüç-Kunt, A., E. López Córdova, M. S. Martínez Pería, and C. Woodruff (2008). 'Remittances and Banking Services: Evidence from Mexico'. Paper presented at the 'Remittances and the Macroeconomy' conference, held at the Federal Reserve Bank of Atlanta, February 21-22.

Dixit, A. (2007). 'Evaluating Recipes for Development Success'. World Bank Research Observer, 22: 131-57.

Easterly, W. (2006). 'Reliving the 50s: The Big Push, Poverty Traps, and Takeoffs in Economic Development'. Journal of Economic Growth, 11: 289-318.

— (2009). 'Can the West Save Africa?'. Journal of Economic Literature, 47: 373-447.

Hausmann, R., J. Hwang and D. Rodrik (2007). 'What you Export Matters'. Journal of Economic Growth, 12: 1-25.

Hernández, R. (2004). 'On the Age against the Poor: Dominican Migration to the United States’. Immigrant \& Refugee Services, 2: 87-107.

Jorgenson, D. W, M. S. Ho, and K. J. Stiroh (2008). A Retrospective Look at the U.S. Productivity Growth Resurgence’. Journal of Economic Perspectives, 22: 3-24.

Kaplinsky, R. (1993). 'Export Processing Zones in the Dominican Republic: Transforming Manufactures into Commodities’. World Development, 21: 1851-65.

Krugman, P. (1979). 'A Model of Balance-of-Payments Crises'. Journal of Money, Credit and Banking, 11: 311-25.

León, Y. A. (2007). 'The Impact of Tourism on Rural Livelihoods in the Dominican Republic’s Coastal Areas'. Journal of Developing Studies, 43: 340-59.

Lizardo, M., and R. M. Guzmán (2005). 'Coordinación de las Políticas Fiscales y Ambientales en la República Dominicana’. Serie Medio Ambiente y Desarrollo 100. Santiago: United Nations Economic Commission for Latin America and the Caribbean (ECLAC).

Lucas, R. E., Jr. (2009). 'Trade and the Diffusion of the Industrial Revolution'. American Economic Journal: Macroeconomics, 1: 1-25. 
McHugh, J. and W. Keller (2002). 'Trade Reforms Continue'. In J. Cardoso and P. M. Young (eds), The Dominican Republic: Stabilization, Structural Reform, and Economic Growth. IMF Occasional Paper 206. Washington, DC: IMF.

Mundra, K. (2005). 'Immigration and International Trade: A Semiparametric Empirical Investigation'. Journal of International Trade and Economic Development, 14: 6591.

Ocampo, J. A. (2004). 'Latin America's Growth and Equity Frustrations During Structural Reforms'. Journal of Economic Perspectives, 18: 67-88.

Portes, A., and L. E. Guarnizo (1991). Tropical Capitalists: US-bound Immigration and Small Enterprise Development in the Dominican Republic'. In S. Díaz-Briquets and S. Weintraub (eds), Migration, Remittances, and Small Business Development. Boulder, CO: Westview Press.

Pozo, S., J. R. Sánchez-Fung, and A. U. Santos-Paulino (2011). 'A Note on Modelling Economic Growth Determinants in the Dominican Republic'. Macroeconomics and Finance in Emerging Market Economies, forthcoming.

Prazmowski, P. A. (2002). 'Endogenous Credibility and Stabilization Programmes: Evidence from the Dominican Republic’. Applied Economics Letters, 9: 933-7

Rodrik, D. (2007). One Economics, Many Recipes: Globalization, Institutions, and Economic Growth. Princeton, NJ: Princeton University Press.

Santos-Paulino, A. U. (2006). 'Trade Liberalisation and Trade Performance in the Dominican Republic'. Journal of International Development, 18: 925-44.

(2008). 'Export Productivity and Specialization in China, Brazil, India and South Africa’. Research Paper. 2008/28. Helsinki: UNU-WIDER.

_ (2010). 'The Dominican Republic Trade Policy Review 2008'. World Economy, forthcoming.

Solimano, A. (ed.) (2008). The International Mobility of Talent: Types, Causes, and Development Impact. Oxford: Oxford University Press for UNU-WIDER.

Thirlwall, A. P. (2004). 'The Mobilisation of Savings for Growth and Development in Developing Countries'. Working Paper 5. Santo Domingo: Central Bank of the Dominican Republic, Research Department.

World Bank (2008). Migration and Remittances Factbook. Washington, DC: World Bank.

World Trade Organization (WTO) (1996). 'Dominican Republic Trade Policy Review'. Geneva: WTO. 
Table 1

Latin America: per capita real GDP growth rate (\%) Descriptive statistics for $1970-2003$

\begin{tabular}{llllll}
\hline Country & Mean & SD & Min & Max & Kurtosis \\
\hline Argentina & 0.27 & 5.40 & -10.56 & 10.68 & 2.35 \\
Bolivia & 0.46 & 2.74 & -8.00 & 4.75 & 4.42 \\
Brazil & 2.02 & 4.19 & -6.87 & 10.39 & 2.56 \\
Chile & 2.23 & 5.96 & -16.34 & 10.22 & 6.12 \\
Colombia & 1.78 & 1.82 & -2.04 & 6.65 & 3.18 \\
Costa Rica & 1.43 & 3.32 & -9.34 & 7.70 & 4.94 \\
Dominican Republic & 3.19 & 3.84 & -5.65 & 13.04 & 3.40 \\
Ecuador & 1.64 & 5.15 & -9.25 & 21.28 & 7.80 \\
El Salvador & 0.78 & 2.84 & -7.34 & 4.89 & 4.07 \\
Guatemala & 0.63 & 2.24 & -4.00 & 6.68 & 3.30 \\
Haiti* & 0.70 & 5.73 & -9.83 & 12.57 & 2.96 \\
Mexico & 1.45 & 3.57 & -7.91 & 6.36 & 3.65 \\
Nicaragua & -1.58 & 5.33 & -19.13 & 6.74 & 5.18 \\
Panama & 2.44 & 4.47 & -9.27 & 18.53 & 7.34 \\
Paraguay & 1.51 & 3.40 & -4.45 & 8.33 & 2.55 \\
Peru & 0.19 & 5.78 & -16.15 & 9.77 & 4.30 \\
USA & 2.07 & 2.31 & -2.92 & 6.85 & 2.62 \\
Uruguay & 1.26 & 5.73 & -14.83 & 10.04 & 3.65 \\
Venezuela & -0.41 & 5.39 & -11.14 & 8.45 & 2.11 \\
\hline
\end{tabular}
$\begin{array}{lllllll}\text { Notes: } & \text { Data are from } & \text { World } \begin{array}{c}\text { Penn } \\ \text { http://pwt.econ.upenn.edu/php_site/pwt_index.php). }\end{array} & \text { Tables } & 6.2 & \text { (available } & \text { at: }\end{array}$

*indicates that this series corresponds to 1971-2000 due to data availability from World Penn Tables.

SD: standard deviation. 
Table 2

Dominican Republic: main agricultural and mineral exports (selected years)

\begin{tabular}{|c|c|c|c|c|c|c|c|c|c|c|c|c|c|}
\hline \multirow{3}{*}{ Year } & \multicolumn{8}{|c|}{ Commodities } & \multirow{2}{*}{\multicolumn{2}{|c|}{ Minerals }} & \multirow{2}{*}{\multicolumn{2}{|c|}{ Total exports (\%) }} & \multirow{3}{*}{ Total exports } \\
\hline & \multicolumn{2}{|c|}{ Coffee } & \multicolumn{2}{|c|}{ Сосоа } & \multicolumn{2}{|c|}{ Sugar } & \multicolumn{2}{|c|}{ Tobbaco } & & & & & \\
\hline & Value & Price & Value & Price & Value & Price & Value & Price & Value & Price & Commodities & Minerals & \\
\hline 1971 & 23.8 & 0.9 & 12.6 & 0.4 & 139.4 & - & 20.7 & 0.8 & 31.9 & 0.9 & 71.6 & 11.6 & 274.5 \\
\hline 1972 & 29.8 & 1.0 & 17.6 & 0.5 & 168.6 & - & 31.9 & 0.9 & 61.9 & 0.6 & 60.4 & 15.1 & 410.8 \\
\hline 1973 & 45.6 & 1.2 & 23.5 & 0.9 & 197.9 & - & 31.3 & 1.0 & 98.3 & 1.4 & 58.2 & 19.2 & 513.0 \\
\hline 1974 & 45.1 & 1.3 & 44.7 & 1.7 & 339.5 & - & 52.5 & 0.9 & 110.8 & 1.6 & 66.1 & 15.2 & 729.5 \\
\hline 1975 & 42.6 & 1.4 & 27.1 & 1.2 & 575.7 & - & 35.6 & 1.1 & 145.8 & 1.3 & 68.3 & 14.6 & 997.6 \\
\hline 1976 & 100.3 & 2.4 & 47.1 & 1.8 & 264.1 & - & 39.4 & 1.2 & 181.1 & 1.9 & 54.6 & 21.9 & 825.4 \\
\hline 1977 & 185.6 & 2.3 & 94.9 & 3.7 & 232.0 & - & 29.3 & 1.5 & 168.4 & 1.4 & 59.0 & 18.3 & 917.9 \\
\hline 1978 & 96.7 & 3.5 & 86.1 & 3.1 & 181.4 & - & 46.3 & 1.2 & 168.6 & 2.3 & 49.6 & 20.4 & 828.0 \\
\hline 1979 & 157.0 & 3.6 & 75.2 & 2.9 & 206.6 & - & 53.9 & 1.3 & 272.1 & 2.3 & 43.4 & 24.0 & $1,134.9$ \\
\hline 1980 & 77.2 & 3.0 & 53.8 & 2.2 & 307.5 & - & 34.1 & 1.6 & 379.3 & 2.6 & 37.2 & 29.8 & $1,271.0$ \\
\hline 1981 & 75.5 & 2.4 & 48.2 & 1.7 & 538.1 & - & 67.4 & 1.7 & 334.0 & 2.7 & 48.2 & 22.1 & $1,513.0$ \\
\hline 1982 & 96.9 & 2.7 & 57.5 & 1.4 & 283.6 & - & 24.4 & 1.8 & 193.0 & 2.3 & 40.5 & 16.9 & $1,142.0$ \\
\hline 1983 & 76.2 & 2.6 & 58.2 & 1.7 & 275.7 & - & 24.1 & 1.6 & 248.0 & 1.7 & 35.0 & 20.0 & $1,242.0$ \\
\hline 1985 & 94.7 & 2.8 & 63.3 & 2.0 & 193.3 & - & 63.3 & 1.7 & 240.3 & 0.4 & 14.2 & 8.2 & 2,914.0 \\
\hline 1986 & 115.6 & 3.7 & 65.4 & 1.7 & 149.6 & - & 68.1 & 1.3 & 234.3 & 0.9 & 28.1 & 16.5 & $1,420.2$ \\
\hline 1987 & 63.2 & 2.2 & 71.0 & 1.8 & 146.8 & - & 66.4 & 1.6 & 189.6 & 1.8 & 23.3 & 12.7 & $1,491.3$ \\
\hline 1988 & 65.3 & 2.5 & 67.5 & 1.4 & 157.1 & - & 73.1 & 1.4 & 239.4 & 3.3 & 24.4 & 16.1 & $1,489.6$ \\
\hline 1992 & 27.1 & 1.2 & 35.3 & 0.7 & 138.7 & 26.1 & 72.7 & 1.3 & 205.3 & 1.8 & 15.4 & 11.6 & $1,774.6$ \\
\hline 1993 & 25.7 & 1.3 & 36.9 & 0.8 & 127.2 & 26.3 & 66.3 & 1.1 & 132.3 & 2.2 & 11.4 & 5.9 & $2,237.9$ \\
\hline 1994 & 62.9 & 3.1 & 55.0 & 1.1 & 129.1 & 25.5 & 60.2 & 1.7 & 201.7 & 2.1 & 12.8 & 8.4 & $2,392.8$ \\
\hline 1995 & 88.3 & 2.9 & 66.7 & 1.1 & 121.8 & 26.3 & 101.1 & 1.3 & 286.9 & 2.8 & 17.7 & 13.4 & $2,140.9$ \\
\hline 1996 & 63.0 & 2.3 & 63.3 & 1.2 & 151.8 & 29.1 & 49.1 & 1.4 & - & 1.9 & 14.2 & - & 2,310.5 \\
\hline 1997 & 67.9 & 3.6 & 62.0 & 1.4 & 174.3 & 28.5 & 90.7 & 3.7 & 243.8 & 2.0 & 13.4 & 8.3 & 2,939.7 \\
\hline 2001 & 11.1 & 1.9 & 40.9 & 1.0 & 68.7 & 28.0 & 32.9 & 0.9 & 145.2 & 7.7 & 4.5 & 4.2 & $3,446.3$ \\
\hline
\end{tabular}

Note: values in million US\$, price is US $\$ 100,000 /$ ton. Commodities as $\%$ of total exports refer to cocoa, coffee, sugar and minerals (ferronickel, doré, bauxite).

Source: UN Comtrade (available at: http://comtrade.un.org/db/default.aspx) and FAOSTAT, FAO Statistics Division (available at: http://faostat.fao.org/) 
Table 3

Dominican Republic: exports and trade balance (selected years)

\begin{tabular}{|c|c|c|c|c|c|c|c|c|c|c|c|}
\hline \multirow[t]{2}{*}{ Year } & \multirow[b]{2}{*}{ Merchandise } & \multirow{2}{*}{$\begin{array}{l}\text { Exports } \\
\text { Agriculture } \\
\text { \& minerals }\end{array}$} & \multirow[b]{2}{*}{ Services } & \multicolumn{2}{|c|}{ Total exports } & \multicolumn{2}{|c|}{$\begin{array}{l}\text { Percentage of } \\
\text { merchandise }\end{array}$} & \multicolumn{3}{|c|}{ Percentage of total goods \& services } & \multirow{2}{*}{$\begin{array}{l}\text { Current } \\
\text { account } \\
\text { balance } \\
(\% \text { of } \\
\text { GDP) }\end{array}$} \\
\hline & & & & Goods & $\begin{array}{l}\text { Goods \& } \\
\text { services }\end{array}$ & Manufactures & $\begin{array}{l}\text { Agriculture } \\
\& \text { minerals }\end{array}$ & Merchandise & $\begin{array}{l}\text { Agriculture } \\
\& \text { minerals }\end{array}$ & Services & \\
\hline 1971 & 151 & 92 & 45 & 243 & 288 & 62.1 & 37.9 & 52.5 & 32.0 & 15.5 & -7.8 \\
\hline 1972 & 183 & 165 & 59 & 348 & 406 & 52.5 & 47.5 & 44.9 & 40.7 & 14.4 & -2.4 \\
\hline 1973 & 182 & 260 & 67 & 442 & 509 & 41.1 & 58.9 & 35.7 & 51.2 & 13.1 & -4.1 \\
\hline 1974 & 334 & 303 & 88 & 637 & 725 & 52.5 & 47.5 & 46.1 & 41.8 & 12.2 & -8.2 \\
\hline 1975 & 565 & 328 & 109 & 894 & 1,003 & 63.3 & 36.7 & 56.4 & 32.7 & 10.9 & -2.0 \\
\hline 1976 & 266 & 451 & 121 & 716 & 838 & 37.1 & 62.9 & 31.7 & 53.8 & 14.5 & -3.3 \\
\hline 1977 & 226 & 555 & 144 & 780 & 924 & 28.9 & 71.1 & 24.4 & 60.0 & 15.5 & -2.8 \\
\hline 1978 & 239 & 436 & 150 & 676 & 826 & 35.4 & 64.6 & 29.0 & 52.8 & 18.2 & -6.5 \\
\hline 1979 & 228 & 640 & 262 & 869 & 1,131 & 26.3 & 73.7 & 20.2 & 56.6 & 23.2 & -6.0 \\
\hline 1980 & 587 & 630 & 305 & 1,217 & 1,522 & 48.3 & 51.7 & 38.6 & 41.4 & 20.0 & -10.9 \\
\hline 1981 & 872 & 585 & 317 & 1,457 & 1,774 & 59.9 & 40.1 & 49.2 & 33.0 & 17.9 & -5.4 \\
\hline 1982 & 594 & 390 & 368 & 984 & 1,352 & 60.4 & 39.6 & 43.9 & 28.9 & 27.2 & -5.6 \\
\hline 1983 & 601 & 482 & 451 & 1,083 & 1,534 & 55.5 & 44.5 & 39.2 & 31.4 & 29.4 & -4.8 \\
\hline 1984 & 730 & 524 & 497 & 1,254 & 1,751 & 58.2 & 41.8 & 41.7 & 29.9 & 28.4 & -1.6 \\
\hline
\end{tabular}




\begin{tabular}{llllllllllll}
1985 & 679 & 549 & 579 & 1,228 & 1,807 & 55.3 & 44.7 & 37.6 & 30.4 & 32.1 & -2.1 \\
1986 & 895 & 417 & 687 & 1,312 & 1,999 & 68.2 & 31.8 & 44.8 & 20.9 & 34.4 & -3.0 \\
1987 & 997 & 501 & 847 & 1,498 & 2,345 & 66.6 & 33.4 & 42.5 & 21.4 & 36.1 & -6.2 \\
1988 & 1,170 & 793 & 1,006 & 1,963 & 2,969 & 59.6 & 40.4 & 39.4 & 26.7 & 33.9 & -0.4 \\
1989 & 1,351 & 890 & 1,032 & 2,241 & 3,273 & 60.3 & 39.7 & 41.3 & 27.2 & 31.5 & -4.9 \\
1990 & 1,479 & 691 & 1,086 & 2,170 & 3,256 & 68.2 & 31.8 & 45.4 & 21.2 & 33.4 & -4.0 \\
1991 & 1,839 & 610 & 1,187 & 2,449 & 3,636 & 75.1 & 24.9 & 50.6 & 16.8 & 32.6 & -1.6 \\
1992 & 2,302 & 529 & 1,337 & 2,831 & 4,168 & 81.3 & 18.7 & 55.2 & 12.7 & 32.1 & -6.3 \\
1993 & 2,735 & 476 & 1,491 & 3,211 & 4,702 & 85.2 & 14.8 & 58.2 & 10.1 & 31.7 & -4.1 \\
1994 & 3,056 & 397 & 1,737 & 3,453 & 5,190 & 88.5 & 11.5 & 58.9 & 7.6 & 33.5 & -2.0 \\
1995 & 3,318 & 462 & 1,894 & 3,780 & 5,674 & 87.8 & 12.2 & 58.5 & 8.1 & 33.4 & -1.1 \\
1996 & 3,476 & 577 & 2,078 & 4,053 & 6,131 & 85.8 & 14.2 & 56.7 & 9.4 & 33.9 & -1.2 \\
1997 & 4,106 & 508 & 2,373 & 4,614 & 6,987 & 89.0 & 11.0 & 58.8 & 7.3 & 34.0 & -0.8 \\
2001 & 4,929 & 347 & 3,024 & 5,276 & 8,300 & 93.4 & 6.6 & 59.4 & 4.2 & 36.4 & -3.0 \\
\hline
\end{tabular}

Note: Commercial Services exclude government's services.

Source: UN Comtrade, World Bank World Development Indicators online (2009). 
Table 4

Dominican Republic: FTZs economic activity

\begin{tabular}{cccccccc}
\hline Year & $\begin{array}{c}\text { Number of } \\
\text { companies }\end{array}$ & $\begin{array}{c}\text { Number of } \\
\text { employees } \\
\text { (thousands) }\end{array}$ & $\begin{array}{c}\text { Weekly } \\
\text { average } \\
\text { salary } \\
\text { RD\$ }\end{array}$ & $\begin{array}{c}\text { Foreign } \\
\text { exchange } \\
\text { generated }\end{array}$ & $\begin{array}{c}\text { Textile } \\
\text { exports** }\end{array}$ & $\begin{array}{c}\text { Total } \\
\text { FTZ } \\
\text { exports }\end{array}$ & $\begin{array}{c}\text { Textile } \\
\text { exports/ } \\
\text { total FTZ of US\$ } \\
\text { exports (\%) }\end{array}$ \\
\hline 1980 & 71 & 16.4 & $\ldots$ & 45 & $\ldots$ & 276 & $\ldots$ \\
1985 & 136 & 30.9 & $\ldots$ & 45 & $\ldots$ & 277 & $\ldots$ \\
1990 & 331 & 130.0 & $\ldots$ & 196 & $\ldots$ & 850 & $\ldots$ \\
1991 & 366 & 135.3 & $\ldots$ & 250 & $\ldots$ & 1,053 & $\ldots$ \\
1992 & 404 & 141.1 & 307.2 & 306 & $\ldots$ & 1,195 & $\ldots$ \\
1993 & 462 & 164.3 & 297.2 & 401 & 1,458 & 2,609 & 55.9 \\
1994 & 467 & 176.3 & 496.7 & 441 & 1,616 & 2,716 & 59.5 \\
1995 & 469 & 165.6 & 539.9 & 512 & 1,787 & 2,907 & 61.5 \\
1996 & 436 & 164.3 & 576.9 & 545 & 1,802 & 3,107 & 57.9 \\
1997 & 446 & 182.2 & 634.3 & 698 & 2,273 & 3,596 & 63.2 \\
1998 & 496 & 196.0 & 638.3 & 827 & 2,395 & 4,100 & 58.4 \\
1999 & 473 & 191.1 & 701.2 & 887 & 2,385 & 4,332 & 55.1 \\
2000 & 481 & 195.3 & 716.5 & 1,018 & 2,451 & 4,771 & 53.9 \\
2001 & 512 & 175.1 & 775.5 & 978 & 2,275 & 4,482 & 50.8 \\
2002 & 520 & 170.1 & 786.6 & 947 & 2,174 & 4,336 & 50.1 \\
\hline
\end{tabular}

Note: $\quad$ *The surrender requirements for the FTZ foreign exchange earnings were eliminated in 1992. Currently, the foreign exchange generated is an estimation of local expenditures of FTZ enterprises.

** These exports are for the North American market.

Source: Dominican Republic's Free Trade Zone National Council, Statistic Report (various issues, available online at: http://www.cnzfe.gov.do/estadisticas.htm). 
Table 5

Latin America: engagement with the rest of the world via migration, 2005

\begin{tabular}{lccc}
\hline \multicolumn{1}{c}{ Country } & $\begin{array}{c}\text { Emigrants as a per } \\
\text { cent of the population }\end{array}$ & $\begin{array}{c}\text { Immigrants as a } \\
\text { per cent of the } \\
\text { population }\end{array}$ & $\begin{array}{c}\text { Emigrants and immigrants as } \\
\text { a per cent of the population }\end{array}$ \\
\hline Argentina & 2.1 & 3.9 & 6.0 \\
Bolivia & 4.6 & 1.3 & 5.9 \\
Chile & 3.6 & 1.4 & 5.0 \\
Colombia & 4.3 & 0.3 & 4.6 \\
Costa Rica & 2.9 & 10.2 & 13.1 \\
Dominican Republic & 12.0 & 1.8 & 13.8 \\
Ecuador & 7.7 & 0.9 & 8.6 \\
Guatemala & 5.4 & 0.4 & 5.8 \\
Haiti & 9.8 & 0.4 & 10.2 \\
Nicaragua & 12.5 & 0.5 & 13.0 \\
Mexico & 10.7 & 0.6 & 11.3 \\
Panama & 6.7 & 3.2 & 9.9 \\
Paraguay & 6.8 & 2.7 & 9.5 \\
Peru & 3.2 & 0.2 & 3.4 \\
Uruguay & 8.3 & 2.4 & 10.7 \\
Venezuela & 1.7 & 3.8 & 5.5 \\
\hline
\end{tabular}

Source: World Bank (2008). 
Figure 1

Dominican Republic: growth rate of real per capita GDP (\%) and trend (grey line), 1969-2003

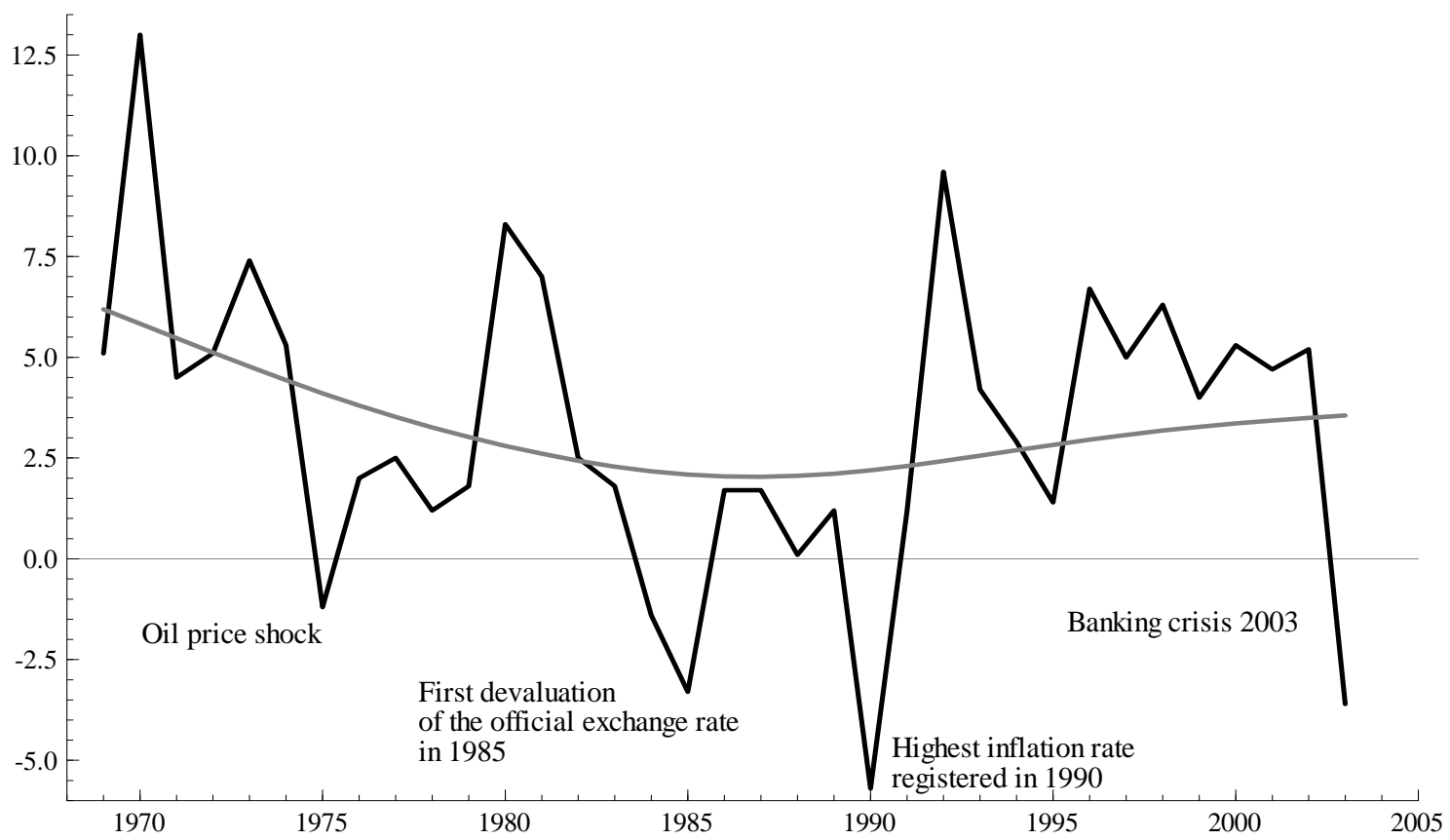

Source: Penn World Table 6.2. 
Figure 2

Dominican Republic: percent of tourist by geographic region

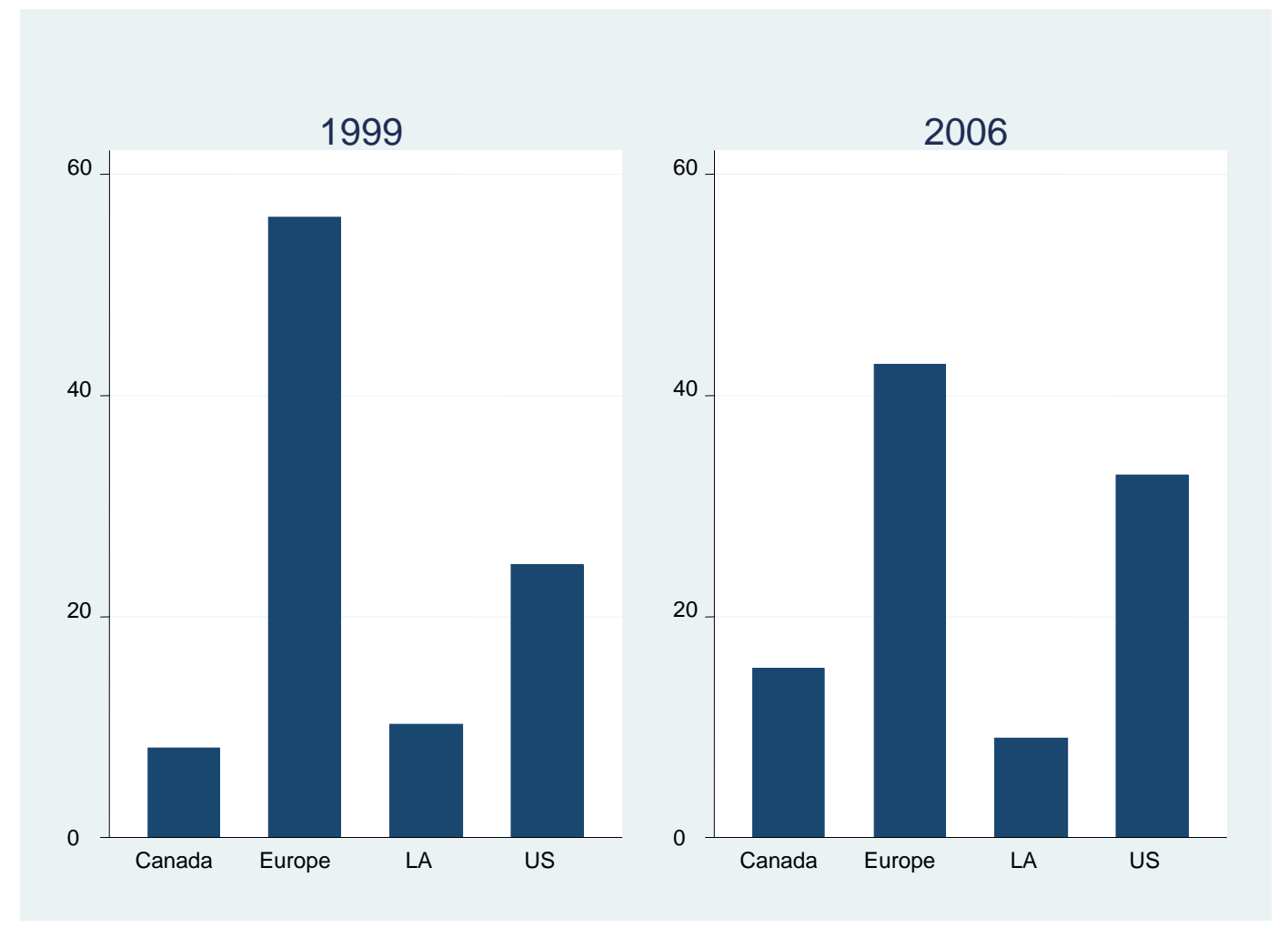

Note: LA: Latin America.

Source: computed by the authors using information from the Central Bank of the Dominican Republic (available at: http://www.bancentral.gov.do/estadisticas.asp?a=Sector_Turismo). 
Figure 3

Dominican Republic: national and FTZs exports

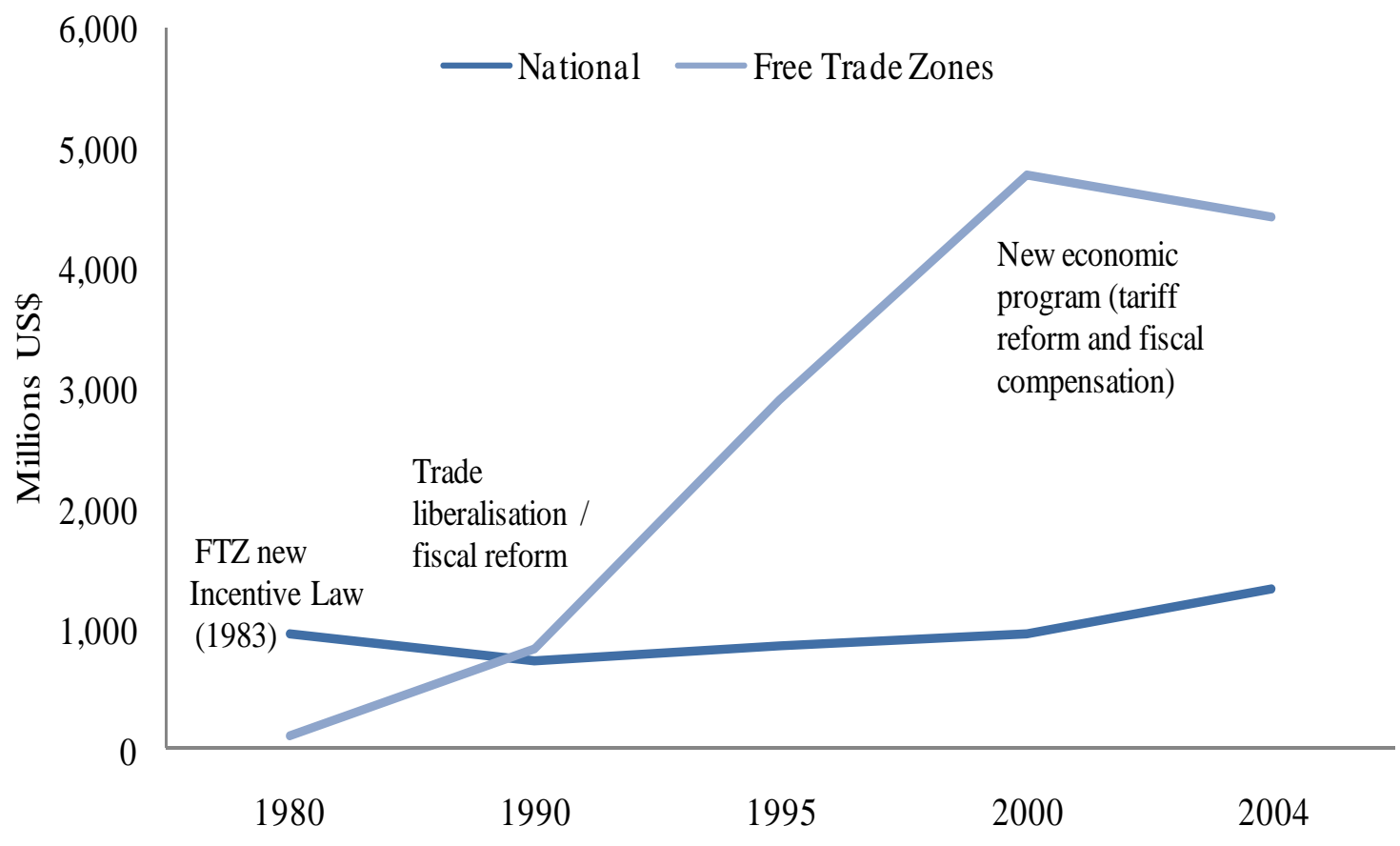

Source: Santos-Paulino (2006). 
Figure 4

Scatterplot of household remittance receipt and availability of telephone by province

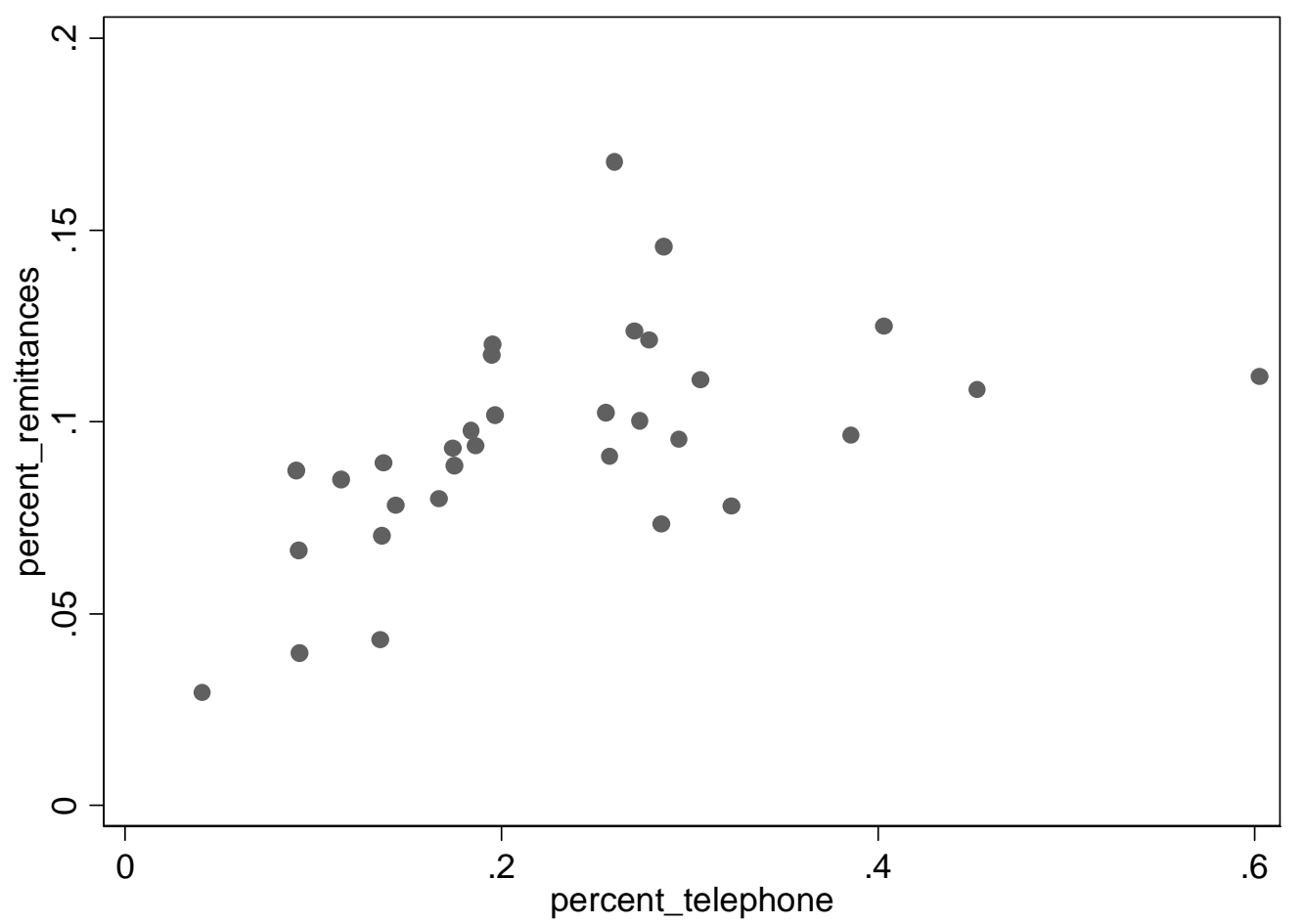

Source: Dominican Republic, VIII National Census of Population and Housing, 2002, Data obtained using the RADATAM SP+ . Available online at:

http://onedatabase.indotel.net.do/cgibin/RpWebEngine.exe/PortalAction?\&MODE=MAIN\&BASE=CPV2002 \&MAIN=WebServerMain.inl 
Figure 5

Growth rates of RGDP (Selected Latin American nations)
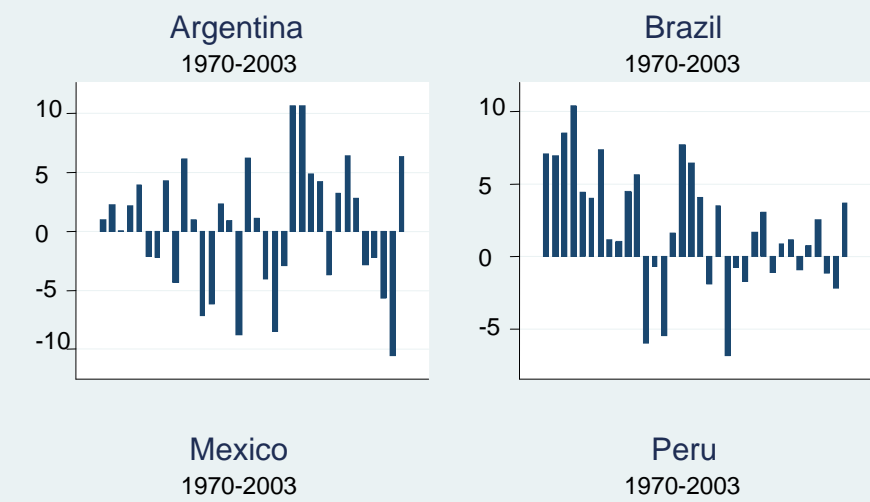
Dominican Republic
1970-2003
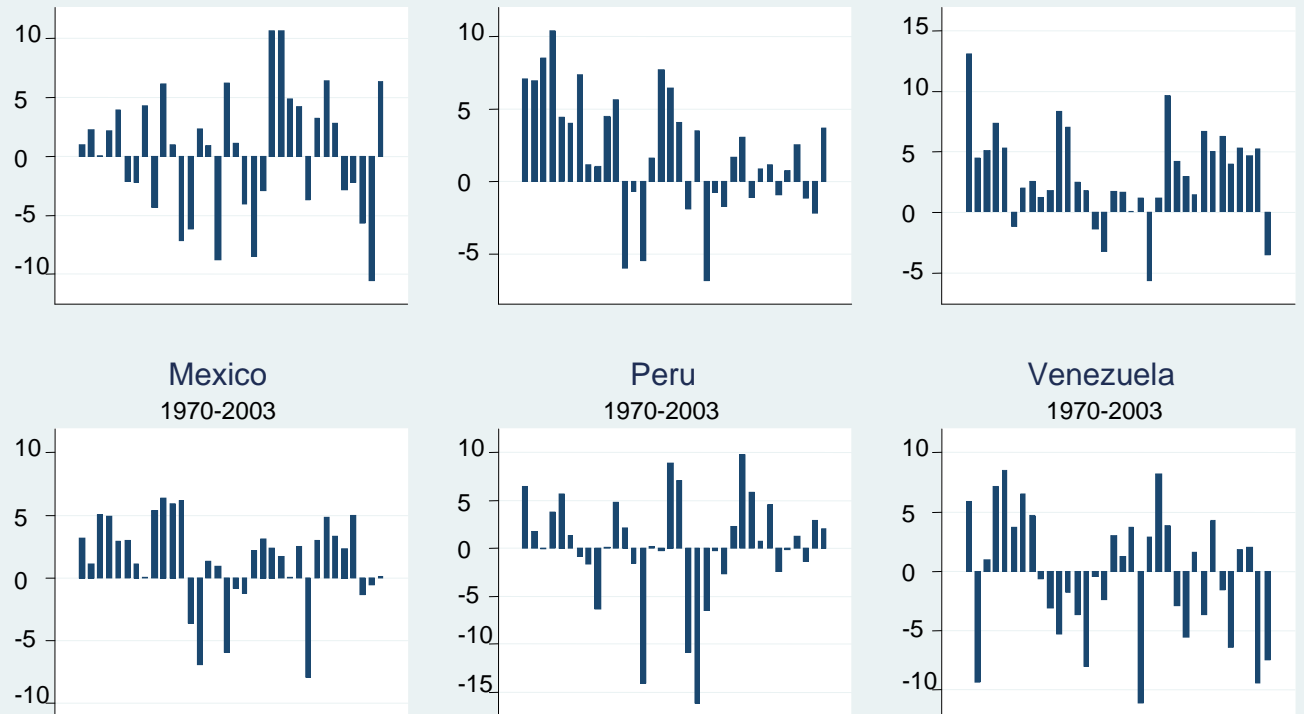

Source: Penn World Table 6.2. 